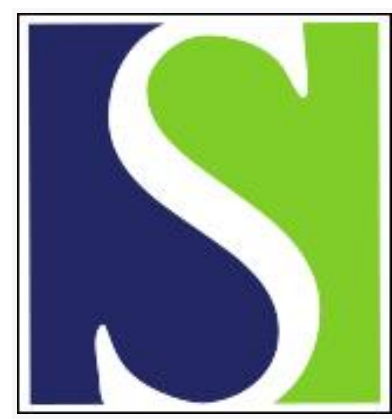

Scand J Work Environ Health 1995;21(5):368-375

https://doi.org/10.5271/sjweh.51

Issue date: Oct 1995

Decreased birth weight in infants born to women with a high dietary intake of fish contaminated with persistent organochlorine compounds

by Rylander L, Strömberg U, Hagmar L

The following article refers to this text: 2002;28(2):124-132

Key terms: birth weight; contamination; decreased birth weight; dietary intake; fish; gender ratio; infant; PCP; persistent organochlorine compound; polychlorinated biphenyl; polychlorinated dibenzo-p-dioxin; polychlorinated dibenzofuran; woman

This article in PubMed: www.ncbi.nlm.nih.gov/pubmed/8571093

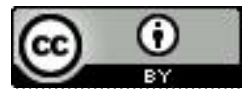




\title{
Decreased birthweight among infants born to women with a high dietary intake of fish contaminated with persistent organochlorine compounds
}

\author{
by Lars Rylander, BSc, ${ }^{1}$ UIf Strömberg, PhD, ${ }^{1}$ Lars Hagmar, $M D^{1}$
}

\begin{abstract}
Rylander L, Strömberg U, Hagmar L. Decreased birthweight among infants born to women with a high dietary intake of fish contaminated with persistent organochlorine compounds. Scand J Work Environ Health 1995;21:368-75.

Objectives The purpose of the study was to assess reproductive outcomes, especially birthweight, and the consumption of fatty fish from the Baltic Sea, contaminated with persistent organochlorine compounds, among women from the Swedish east coast.

Material and methods Cohorts of fishermen's wives from the Swedish east and west coasts were established and linked to the Swedish Medical Birth Register for 1973-1991; 1501 children were born in the eastcoast cohort and 3553 in the westcoast cohort. Comparisons were made with regional populations and between the cohorts. Dietary interviews were made with 69 randomly selected women from the cohorts and 69 referents.

Results The women interviewed from the east- and westcoast cohorts ate locally caught fish more than twice as often as their referents. Compared with the regional population, the women in the eastcoast cohort gave birth to an increased number of infants with low birthweights $(<3000 \mathrm{~g})$, whereas the opposite was seen in the westcoast cohort. Infants in the eastcoast cohort had significantly lower birthweights than infants from the westcoast cohort (median 3530 versus $3610 \mathrm{~g}, \mathrm{P}<0.001$ ). Even after adjustment for potential confounders, eastcoast affiliation showed an increased risk for low birthweight (odds ratio 1.44, 95\% confidence interval $1.18-1.76$ ). The effect was more conspicuous for boys (odds ratio 1.95) and heavy smokers (odds ratio 3.00). Conclusions The present data support, but do not prove, an association between a high consumption of contaminated fish from the Baltic Sea and an increased risk for low birthweight.
\end{abstract}

Key terms polychlorinated biphenyls, polychlorinated dibenzofurans, polychlorinated dibenzo-p-dioxins, gender ratio.

Prenatal exposure to polychlorinated biphenyls (PCB) has caused developmental toxic effects in litters in experimental animal studies $(1-4)$. Infants born to mothers who had accidentally been poisoned by PCB-contaminated rice bran oil suffered from intrauterine growth retardation (5-8). Even for infants born to mothers with a lower dietary intake of PCB, possible associations have been reported with a low birthweight and poorer cognitive and psychomotor development (9-12).

In Sweden the main exposure route for both PCB and other persistent organochlorine compounds, such as polychlorinated dibenzo-p-dioxins (PCDD) and polychlorinated dibenzofurans (PCDF), is through the consumption of fatty fish species from the Baltic Sea (the eastern coast of Sweden) (13-15). In a recent risk assessment of PCB it was concluded that the present exposure of Nordic populations through fish consumption is of the same magnitude as that at which subtle health effects may occur in children exposed in utero and, possibly, through breast-feeding as well (16). Swedish fishermen have been shown to eat more than twice as much fish as subjects from the general population $(14,17)$. Therefore their wives were considered an appropriate study base for health assessments of perinatal exposure to PCB.

The objectives of our study were to investigate whether fishermen's wives from the Swedish east coast have a higher dietary intake of fatty fish from the Baltic Sea, contaminated with various persistent organochlorine compounds, than women from the general population and to assess their reproductive outcome. For relevant comparison, we used a similar cohort from the Swedish west coast (Skagerrak and Kattegatt), where the contamination of fish is considerably less.

1 Department of Occupational and Environmental Medicine, University Hospital, S-221 85, Lund, Sweden.

Reprint requests to: Mr L Rylander, Department of Occupational and Environmental Medicine, University Hospital, S-221 85 Lund, Sweden. 


\section{Methods}

\section{Cohorts of women}

Cohorts of fishermen from the Swedish east and west coasts have previously been established $(13,17)$. By linkage to the national Swedish population register and to registers at the local parish offices, we identified 1568 women from the east coast and 4027 from the west coast who were, or had been, married to these fishermen and were born in 1923 or later.

\section{Linkage to the Medical Birth Register to establish cohorts of mothers and children}

The women in the cohorts were linked to the Swedish Medical Birth Register, which includes almost every infant born in Sweden since 1973. It is based on copies of record forms for maternity health care, the delivery, and the pediatric examination of the newborn. In $1982 \mathrm{sev}$ eral new variables were introduced into the register, for example, information on maternal smoking habits in early pregnancy (at the first visit to a prenatal health center, usually around week 10-12). During 1973-1991, 757 women from the east coast gave birth to 1501 infants (1.98 infants/woman) and 1834 women from the west coast gave birth to 3553 infants (1.94 infants per woman).

\section{Characteristics of the cohorts}

The annual number of births decreased during the study period in both cohorts (table 1). In the eastcoast cohort there was a slightly higher proportion of mothers giving birth before the age of 25 years (29.8 versus $27.4 \%$ ), but the medians for maternal age were identical for the two cohorts (27 years). Neither parity nor gestational length differed between the cohorts. It is important to note that a lower proportion of the westcoast women smoked during early pregnancy (22.7 versus $38.0 \%$ ). Unfortunately, no data on smoking habits in late pregnancy were available. The medians for the height were almost the same in the two cohorts $(166$ versus $167 \mathrm{~cm}$ ), but there was a higher proportion of women shorter than $165 \mathrm{~cm}$ in the eastcoast cohort (48.6 versus $39.2 \%$ ). No differences in weight distribution in early pregnancy were seen between the cohorts.

\section{Dietary interviews}

Dietary telephone interviews were performed with random samples of 38 of the 757 eastcoast women and 31 of the 1834 westcoast women, and with equally many randomly selected reference women from the general population, matched with respect to age and county of living. Five east- and seven westcoast women, and twelve reference women refused to participate in the dietary interviews. Questionnaires were distributed to the interviewed women beforehand, together with color pictures of three
Table 1. Background characteristics of the two cohorts of wives to Swedish fishermen and their children.

\begin{tabular}{|c|c|c|c|c|}
\hline & \multicolumn{2}{|c|}{ East coast } & \multicolumn{2}{|c|}{ West coast } \\
\hline & $\mathrm{N}$ & $\%$ & N & $\%$ \\
\hline Infants born $(\mathrm{N})$ & 1501 & . & 3553 & . \\
\hline Women giving birth ( $\mathrm{N}$ ) & 757 & . & 1834 & . \\
\hline \multicolumn{5}{|l|}{ Calendar year of birth } \\
\hline $\begin{array}{l}1973-1977 \\
1978-1982 \\
1983-1987 \\
1988-1991\end{array}$ & $\begin{array}{l}484 \\
421 \\
366 \\
230\end{array}$ & $\begin{array}{l}32.2 \\
28.0 \\
24.4 \\
15.3\end{array}$ & $\begin{array}{r}1193 \\
925 \\
805 \\
630\end{array}$ & $\begin{array}{l}33.6 \\
26.0 \\
22.7 \\
17.7\end{array}$ \\
\hline \multicolumn{5}{|l|}{ Maternal age (year) } \\
\hline $\begin{array}{l}15-19 \\
20-24 \\
25-29 \\
30-34 \\
35-39 \\
\geq 40\end{array}$ & $\begin{array}{r}54 \\
393 \\
537 \\
336 \\
148 \\
33\end{array}$ & $\begin{array}{r}3.6 \\
26.2 \\
35.8 \\
22.4 \\
9.9 \\
2.2\end{array}$ & $\begin{array}{r}76 \\
899 \\
1374 \\
800 \\
319 \\
85\end{array}$ & $\begin{array}{r}2.1 \\
25.3 \\
38.7 \\
22.5 \\
9.0 \\
2.4\end{array}$ \\
\hline \multicolumn{5}{|l|}{$\begin{array}{l}\text { Weight of the women in } \\
\text { early pregnancy }(\mathrm{kg})^{\mathrm{a}}\end{array}$} \\
\hline $\begin{array}{l}\leq 60 \\
61-70 \\
71-80 \\
\geq 81 \\
\text { Unknown }\end{array}$ & $\begin{array}{r}28 \\
111 \\
175 \\
177 \\
191\end{array}$ & $\begin{array}{r}5.7 \\
22.6 \\
35.6 \\
36.0 \\
.\end{array}$ & $\begin{array}{r}48 \\
319 \\
425 \\
414 \\
400\end{array}$ & $\begin{array}{r}4.0 \\
26.5 \\
35.2 \\
34.3 \\
.\end{array}$ \\
\hline \multicolumn{5}{|l|}{ Height of the women $(\mathrm{cm})^{\mathrm{a}}$} \\
\hline $\begin{array}{l}\leq 160 \\
161-165 \\
166-170 \\
\geq 171 \\
\text { Unknown }\end{array}$ & $\begin{array}{r}91 \\
176 \\
141 \\
141 \\
133\end{array}$ & $\begin{array}{l}16.6 \\
32.0 \\
25.7 \\
25.6\end{array}$ & $\begin{array}{l}182 \\
316 \\
431 \\
340 \\
337\end{array}$ & $\begin{array}{l}14.3 \\
24.9 \\
34.0 \\
26.8\end{array}$ \\
\hline \multicolumn{5}{|l|}{ Parity } \\
\hline $\begin{array}{l}1 \\
2 \\
3 \\
\geq 4 \\
\text { Unknown }\end{array}$ & $\begin{array}{r}473 \\
510 \\
306 \\
171 \\
41\end{array}$ & $\begin{array}{r}32.4 \\
34.9 \\
21.0 \\
11.7 \\
.\end{array}$ & $\begin{array}{r}1125 \\
1209 \\
754 \\
341 \\
124\end{array}$ & $\begin{array}{r}32.8 \\
35.3 \\
22.0 \\
9.9\end{array}$ \\
\hline \multicolumn{5}{|l|}{ Gestational length (weeks) } \\
\hline $\begin{array}{l}\leq 33 \\
34-37 \\
38-40 \\
\geq 41 \\
\text { Unknown }\end{array}$ & $\begin{array}{r}25 \\
103 \\
817 \\
451 \\
105\end{array}$ & $\begin{array}{r}1.8 \\
7.4 \\
58.5 \\
32.3 \\
.\end{array}$ & $\begin{array}{r}48 \\
199 \\
1926 \\
1071 \\
309\end{array}$ & $\begin{array}{r}1.5 \\
6.1 \\
59.4 \\
33.0 \\
.\end{array}$ \\
\hline \multicolumn{5}{|l|}{$\begin{array}{l}\text { Smoking habits in early } \\
\text { pregnancy } \\
\text { (cigarettes per day) }^{\text {a }}\end{array}$} \\
\hline $\begin{array}{l}1-9 \\
\geq 10 \\
\text { Unknown }\end{array}$ & $\begin{array}{r}364 \\
124 \\
98 \\
96\end{array}$ & $\begin{array}{l}62.1 \\
21.2 \\
16.8\end{array}$ & $\begin{array}{r}1120 \\
205 \\
125 \\
156\end{array}$ & $\begin{array}{r}77.2 \\
14.1 \\
8.6 \\
.\end{array}$ \\
\hline
\end{tabular}

a Recorded since 1982.

different sizes of fish portions of four fish species. The present food frequencies for several different food items, as well as coffee, tobacco, and alcohol consumption were assessed, together with the average amount of consumed fish (tables 2 and 3). The women were also asked about their food frequencies today compared with 10 to 20 years ago.

\section{Statistical methods}

The expected birthweight distributions were calculated from the data from the Medical Birth Register for the regional reference populations with adjustments for year 
Table 2. Consumption of certain foods, coffee, and alcohol for 38 women from the east coast and 31 from the west coast, randomly selected from the cohorts, and 69 referents, matched by age and county.

\begin{tabular}{|c|c|c|c|c|c|c|c|c|c|c|c|}
\hline & \multicolumn{5}{|c|}{ Fishermen's wives } & \multicolumn{6}{|c|}{ Referents } \\
\hline & \multicolumn{2}{|c|}{$\begin{array}{l}\text { East coast } \\
(N=38)\end{array}$} & \multicolumn{2}{|c|}{$\begin{array}{l}\text { West coast } \\
(N=31)\end{array}$} & \multirow[t]{2}{*}{$P$-valuea, b } & \multicolumn{2}{|c|}{$\begin{array}{l}\text { East coast } \\
(\mathrm{N}=38)\end{array}$} & \multirow[t]{2}{*}{$P$-value ${ }^{b, c}$} & \multicolumn{2}{|c|}{$\begin{array}{l}\text { West coast } \\
(\mathrm{N}=31)\end{array}$} & \multirow[t]{2}{*}{$P$-value ${ }^{b c}$} \\
\hline & Mean & SD & Mean & $\mathrm{SD}$ & & Mean & SD & & Mean & $\mathrm{SD}$ & \\
\hline \multicolumn{12}{|l|}{$\begin{array}{l}\text { Locally caught fish } \\
\text { (meals } \cdot \text { month }^{-1} \text { ) }\end{array}$} \\
\hline $\begin{array}{l}\text { Lean fish } \\
\text { Fatty fish }\end{array}$ & $\begin{array}{l}3.3 \\
2.1\end{array}$ & $\begin{array}{l}2.8 \\
2.6\end{array}$ & $\begin{array}{l}5.7 \\
2.7\end{array}$ & $\begin{array}{l}3.2 \\
3.1\end{array}$ & $\begin{array}{l}<0.001 \\
>0.5\end{array}$ & $\begin{array}{l}1.3 \\
0.9\end{array}$ & $\begin{array}{l}1.8 \\
1.2\end{array}$ & $\begin{array}{l}<0.001 \\
<0.01\end{array}$ & $\begin{array}{l}2.7 \\
0.7\end{array}$ & $\begin{array}{l}3.3 \\
0.8\end{array}$ & $\begin{array}{r}<0.001 \\
0.003\end{array}$ \\
\hline Total & 5.4 & 4.8 & 8.4 & 4.8 & 0.002 & 2.2 & 2.6 & $<0.001$ & 3.4 & 3.5 & $<0.001$ \\
\hline $\begin{array}{l}\text { Not locally caught fish } \\
\text { (meals } \cdot \text { month }^{-1} \text { ) }\end{array}$ & 0.8 & 1.6 & 1.8 & 2.8 & 0.2 & 3.1 & 2.5 & $<0.001$ & 3.3 & 3.0 & 0.01 \\
\hline $\begin{array}{l}\text { Smoked fish } \\
\text { Shellfish }\end{array}$ & $\begin{array}{l}0.7 \\
1.3\end{array}$ & $\begin{array}{l}1.2 \\
2.4\end{array}$ & $\begin{array}{l}0.2 \\
2.4\end{array}$ & $\begin{array}{l}0.5 \\
1.7\end{array}$ & $\begin{array}{l}0.02 \\
<0.001\end{array}$ & $\begin{array}{l}0.1 \\
1.1\end{array}$ & $\begin{array}{l}0.4 \\
1.2\end{array}$ & $\begin{array}{l}0.002 \\
0.4\end{array}$ & $\begin{array}{l}0.4 \\
1.8\end{array}$ & $\begin{array}{l}0.9 \\
2.4\end{array}$ & $\begin{array}{l}0.4 \\
0.05\end{array}$ \\
\hline $\begin{array}{l}\text { Meat (meals } \cdot \text { month }^{-1} \text { ) } \\
\text { Game (meals } \cdot \text { month } \\
\text { Chicken (meals } \cdot \text { month } \\
\text { Sausages, bacon (meals } \cdot \text { month }^{-1} \text { ) }\end{array}$ & $\begin{array}{l}9.7 \\
1.8 \\
1.8 \\
4.4\end{array}$ & $\begin{array}{l}6.1 \\
4.1 \\
1.6 \\
2.7\end{array}$ & $\begin{array}{l}9.0 \\
0.5 \\
1.7 \\
3.9\end{array}$ & $\begin{array}{l}4.4 \\
1.1 \\
1.6 \\
2.6\end{array}$ & $\begin{array}{r}>0.5 \\
0.2 \\
>0.5 \\
0.4\end{array}$ & $\begin{array}{l}10 \\
0.5 \\
2.1 \\
5.1\end{array}$ & $\begin{array}{l}4.7 \\
1.4 \\
1.6 \\
3.5\end{array}$ & $\begin{array}{l}0.4 \\
0.10 \\
0.3 \\
0.6\end{array}$ & $\begin{array}{l}11 \\
0.6 \\
2.4 \\
3.8\end{array}$ & $\begin{array}{l}5.1 \\
1.4 \\
1.4 \\
2.9\end{array}$ & $\begin{aligned} & 0.13 \\
> & 0.5 \\
& 0.05 \\
> & 0.5\end{aligned}$ \\
\hline $\begin{array}{l}\text { Fresh vegetables (monthly) } \\
\text { Potatoes (monthly) } \\
\text { Fresh fruits (number - month }{ }^{-1} \text { ) }\end{array}$ & $\begin{array}{l}23 \\
22 \\
34\end{array}$ & $\begin{array}{l}9.8 \\
7.0 \\
22\end{array}$ & $\begin{array}{l}25 \\
24 \\
37\end{array}$ & $\begin{array}{l}9.7 \\
7.3 \\
22\end{array}$ & $\begin{array}{r}0.3 \\
0.3 \\
>0.5\end{array}$ & $\begin{array}{l}21 \\
19 \\
37\end{array}$ & $\begin{array}{r}9.8 \\
7.4 \\
22\end{array}$ & 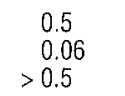 & $\begin{array}{l}25 \\
19 \\
43\end{array}$ & $\begin{array}{l}8.7 \\
6.6 \\
30\end{array}$ & $\begin{array}{c}>0.5 \\
0.01 \\
>0.5\end{array}$ \\
\hline $\begin{array}{l}\left.\text { Coffee (cups } \cdot d^{-1}\right) \\
\text { Alcohol }\left(g \cdot \text { month }^{-1}\right)\end{array}$ & $\begin{array}{r}4.4 \\
105\end{array}$ & $\begin{array}{r}4.1 \\
101\end{array}$ & $\begin{array}{r}4.3 \\
108\end{array}$ & $\begin{array}{r}2.6 \\
131\end{array}$ & $\begin{array}{l}>0.5 \\
>0.5\end{array}$ & $\begin{array}{r}3.7 \\
146\end{array}$ & $\begin{array}{r}2.4 \\
152\end{array}$ & $\begin{array}{r}>0.5 \\
0.2\end{array}$ & $\begin{array}{r}3.6 \\
149\end{array}$ & $\begin{array}{r}2.9 \\
150\end{array}$ & $\begin{array}{l}0.14 \\
0.15\end{array}$ \\
\hline
\end{tabular}

a Comparison between the cohort women from the east and west coast.

- P-values for the Mann-Whitney test.

c Comparison between the cohort women and their local referents.

Table 3. Smoking habits for 38 women from the east coast and 31 women from the west coast, randomly selected from the cohorts, and 69 referents, matched by age and county.

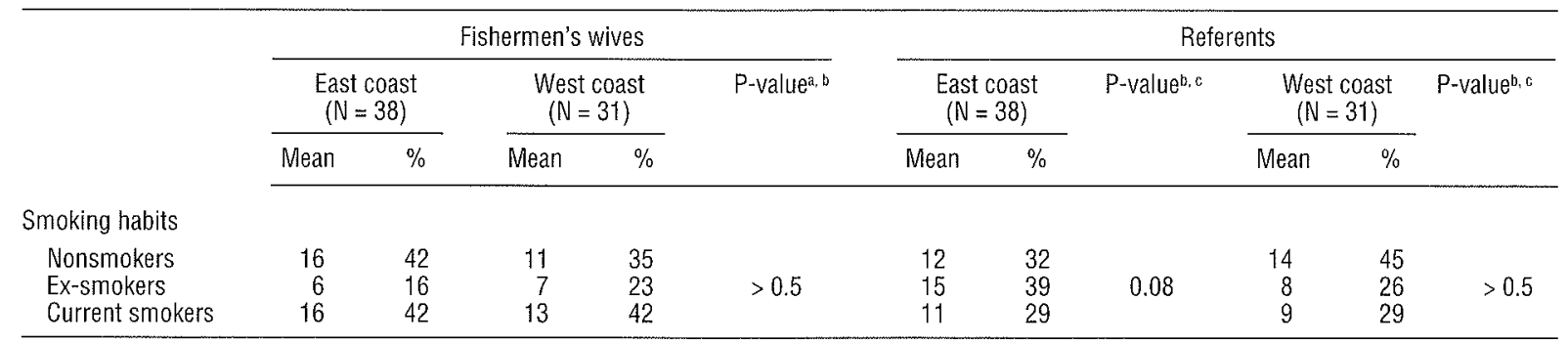

a Comparison between the cohort women from the east and west coast.

b P-values for the chi-square test.

c Comparison between the cohort women and their local referents.

of birth, maternal age, and parity. The differences in the birthweight distributions were evaluated by a chi-square test based on the weight groups $<2000,2000-2499$, $2500-2999,3000-3499,3500-3999,4000-4499$, and $>4500 \mathrm{~g}$. A confidence interval (CI) for the ratio between the observed number of infants with low birthweight (2500 and $3000 \mathrm{~g}$ ) were used as cut points and the corresponding expected number was based on the chisquare distribution. The odds ratio (OR) was used for measuring the effect of cohort affiliation (east or west) on low birthweight and estimated exactly with adjustments for known, potential confounders by stratified analyses (EGRET software, Statistics and Epidemiology Research Corporation, Seattle). A confidence interval for the fraction of boys was calculated using a normal approximation. For statistical testing, we used the chisquare test for categorical variables, and the Mann-Whitney test otherwise. All of the tests employed were twotailed.

\section{Results}

\section{Gender ratio}

The gender ratio in the eastcoast cohort was significantly lower than in the westcoast cohort $(0.98$ versus 1.11 , $\mathrm{P}=0.05)$. The fractions of boys in the east- and westcoast cohorts were $49.6 \%(95 \%$ CI $47.1-52.1)$ and $52.6 \%$ (95\% CI 51.0-54.2), respectively. None of these 
observed gender ratios differed, however, from the 1.06 of the overall Swedish population (18).

\section{Birthweight, length, and head circumference}

The observed birthweight distribution for the eastcoast cohort differed somewhat from the expected distribution (figure $1, P=0.06$ ), due to an increased number of infants with either low or high birthweights. The observed birthweight distribution for the westcoast cohort showed that the infants were somewhat heavier when compared with the expected distribution (figure $2, \mathrm{P}<0.001$ ).

In the eastcoast cohort the ratio between the observed and the expected numbers of low birthweight, using the cutpoint $2500 \mathrm{~g}$, was 1.22 (95\% CI $0.98-1.52$ ) (table 4), while the ratio with respect to the cutpoint $3000 \mathrm{~g}$ was $1.13(95 \%$ CI $1.00-1.27)$, considering all infants. For the westcoast cohort the corresponding ratios were 0.94 (95\% CI $0.79-1.12$ ) and 0.83 (95\% CI $0.75-0.91)$. When the analysis was restricted to infants born during marriage with a fisherman, the ratios decreased in both cohorts (table 4).

A direct comparison between the birthweight distributions in the two cohorts showed a significant difference $(\mathrm{P}<0.001)$ (figure 3 ), with a median of $3530 \mathrm{~g}$ and $3610 \mathrm{~g}$ in the east- and westcoast cohorts, respectively (table 5). Even after adjustment for gender, maternal age, parity, marital status, and smoking habits in early pregnancy, eastcoast cohort affiliation was an indicator for low birthweight, irrespective of whether $2500 \mathrm{~g}$ (OR $1.25,95 \%$ CI $0.87-1.77$ ) or $3000 \mathrm{~g}$ (OR $1.44,95 \% \mathrm{CI}$ $1.18-1.76$ ) was used as the cutpoint (table 6). These calculations were made after the exclusion of multiple

Table 4. Ratios between the observed (0) and expected $(E)$ numbers of infants with low birthweight (cut points 2500 and $3000 \mathrm{~g}$, respectively) for the east- and westcoast cohorts, with the $95 \%$ confidence intervals $(95 \% \mathrm{Cl})$. The expected values were based on the regional reference populations and adjusted for calendar year of birth, maternal age, and parity. Ratios are also presented for the infants born during the marriage with a fisherman.

\begin{tabular}{lrrrr}
\hline Birthweight & 0 & $\mathrm{E}$ & $0: \mathrm{E}$ & $95 \% \mathrm{Cl}$ \\
\hline$<2500 \mathrm{f}$ & & & & \\
$\quad$ Eastcoast cohort & & & & \\
$\quad$ All & 82 & 67 & 1.22 & $0.98-1.52$ \\
$\quad$ During marriage & 45 & 40 & 1.13 & $0.83-1.52$ \\
$\quad$ Westcoast cohort & & & & \\
$\quad$ All & 137 & 145 & 0.94 & $0.79-1.12$ \\
$\quad$ During marriage & 98 & 114 & 0.86 & $0.70-1.05$ \\
$<3000 \mathrm{~g}$ & & & & \\
$\quad$ Eastcoast cohort & & & & \\
$\quad$ All & 268 & 238 & 1.13 & $1.00-1.27$ \\
$\quad$ During marriage & 146 & 140 & 1.04 & $0.88-1.23$ \\
$\quad$ Westcoast cohort & & & & \\
$\quad$ All & 422 & 508 & 0.83 & $0.75-0.91$ \\
$\quad$ During marriage & 308 & 402 & 0.77 & $0.68-0.86$ \\
\hline
\end{tabular}

births and infants with major malformations. The effect was more conspicuous for the boys (OR 1.45 with $2500 \mathrm{~g}$ as the cut point and OR 1.95 with $3000 \mathrm{~g}$ as the cut point) than for the girls (ORs 1.08 and 1.13, respectively). Thus gender appeared as an effect modifier. Restricting the analysis to mothers with known smoking status increased the OR slightly (OR 1.50, 95\% CI 0.79-2.80, using

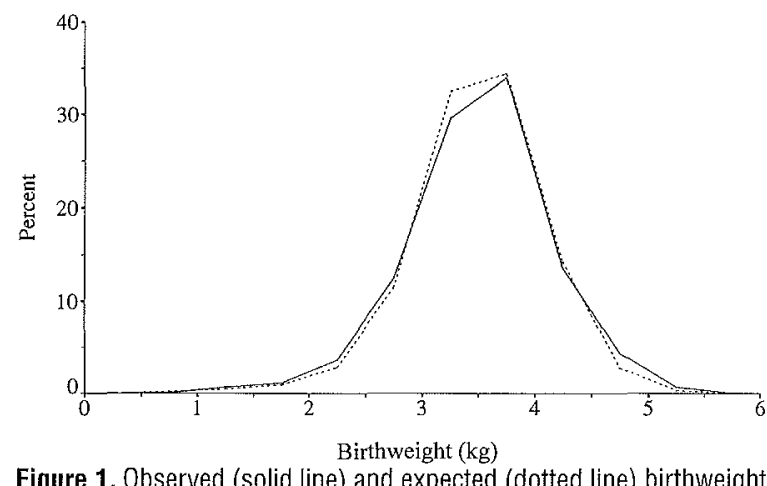

Figure 1. Observed (solid line) and expected (dotted line) birthweight distributions for the eastcoast cohort. The expected distributions were based on data for the regional reference population with adjustment for year of birth, maternal age, and parity.

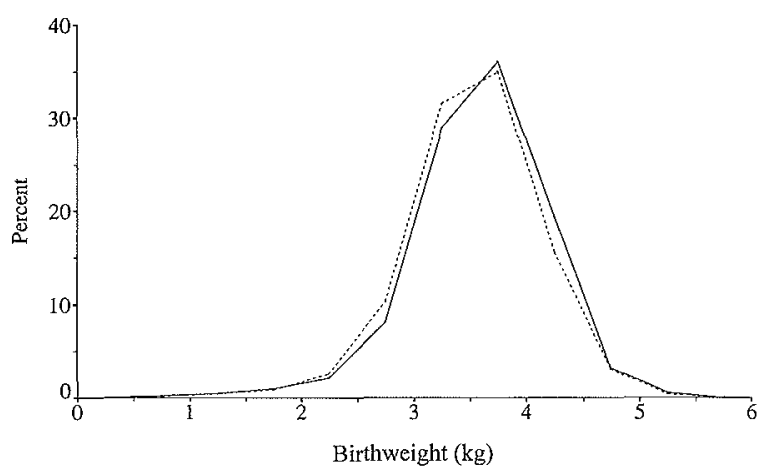

Figure 2. Observed (solid line) and expected (dotted line) birthweight distributions for the westcoast cohort. The expected distributions were based on data for the regional reference population with adjustment for year of birth, maternal age, and parity.

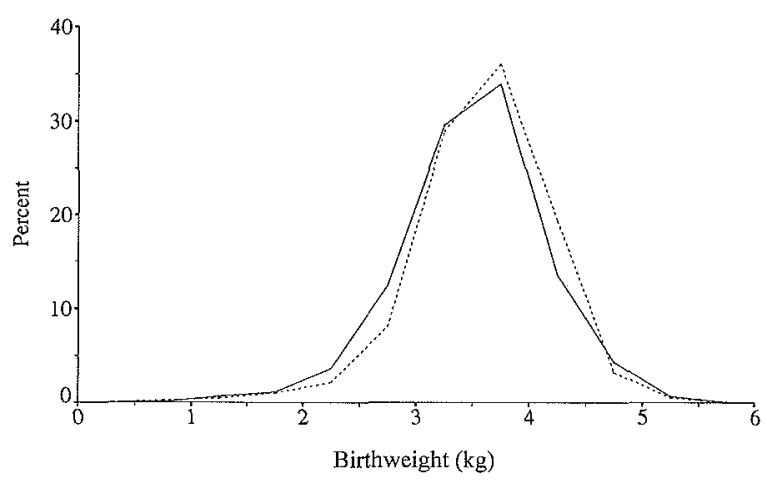

Figure 3. Observed birthweight distributions for the eastcoast (solid line) and westcoast (dotted line) cohorts. 
Table 5. Characteristics of 1501 newborn infants in the eastcoast cohort and 3553 newborn infants in the westcoast cohort.a

\begin{tabular}{|c|c|c|c|c|c|c|c|c|c|c|c|c|c|c|c|}
\hline \multirow[t]{3}{*}{ Cohort } & \multicolumn{3}{|c|}{ Birthweight $(g)$} & \multicolumn{3}{|c|}{ Length at birth $(\mathrm{cm})$} & \multicolumn{9}{|c|}{ Head circumference } \\
\hline & \multirow{2}{*}{ Median } & \multirow{2}{*}{$\begin{array}{c}\text { 10th } \\
\text { per- } \\
\text { centile }\end{array}$} & \multirow{2}{*}{$\begin{array}{c}\text { goth } \\
\text { per- } \\
\text { centile }\end{array}$} & \multirow{2}{*}{ Median } & \multirow{2}{*}{$\begin{array}{c}10 \text { th } \\
\text { per- } \\
\text { centile }\end{array}$} & \multirow{2}{*}{$\begin{array}{c}90 t h \\
\text { per- } \\
\text { centile }\end{array}$} & \multicolumn{2}{|c|}{$\leq 30 \mathrm{~cm}$} & \multicolumn{2}{|c|}{$31-34 \mathrm{~cm}$} & \multicolumn{2}{|c|}{$35-37 \mathrm{~cm}$} & \multicolumn{2}{|c|}{$\geq 38 \mathrm{~cm}$} & \multirow{2}{*}{$\frac{\text { Unknown }}{N}$} \\
\hline & & & & & & & $N$ & $\%$ & $N$ & $\%$ & $\mathrm{~N}$ & $\%$ & $N$ & $\%$ & \\
\hline $\begin{array}{l}\text { East coast } \\
\text { West coast }\end{array}$ & $\begin{array}{c}3530 \\
3610 \\
P<0.0010\end{array}$ & $\begin{array}{l}2760 \\
2920\end{array}$ & $\begin{array}{l}4250 \\
4260\end{array}$ & $\begin{array}{c}51 \\
51 \\
P=0.2^{\circ}\end{array}$ & $\begin{array}{l}48 \\
48\end{array}$ & $\begin{array}{l}54 \\
53\end{array}$ & $\begin{array}{l}30 \\
32\end{array}$ & $\begin{array}{l}2.0 \\
0.9\end{array}$ & $\begin{array}{r}651 \\
1216\end{array}$ & $\begin{array}{c}44.1 \\
34.8 \\
P<0.001^{b}\end{array}$ & $\begin{array}{r}742 \\
2107\end{array}$ & $\begin{array}{l}50.2 \\
60.3\end{array}$ & $\begin{array}{r}54 \\
142\end{array}$ & $\begin{array}{l}3.7 \\
4.1\end{array}$ & $\begin{array}{l}24 \\
56\end{array}$ \\
\hline
\end{tabular}

a Excluding multiple births and infants with major malformation did not affect the observed discrepancies between the cohorts.

b P-values for comparison between the cohorts (chi-square test used for categorical variables and Mann-Whitney test otherwise).

Table 6. Odds ratios $(\mathrm{OR})$, adjusted for maternal age (4 categories: $15-24,25-29,30-39, \geq 40$ years), parity ( 3 categories: 1, 2, $\geq 3$ ), marital status ( 3 categories: before, during, and after marriage to a fisherman), and smoking habits in early pregnancy (4 categories: nonsmokers, $1-9$ cigarettes a day, $\geq 10$ cigarettes a day, unknown) with $95 \%$ confidence intervals $(95 \% \mathrm{Cl})$. Multiple births and major malformations were excluded from the analyzed data.

\begin{tabular}{|c|c|c|c|c|c|c|c|c|c|}
\hline \multirow[t]{2}{*}{ Birthweight } & \multicolumn{3}{|c|}{ Boys } & \multicolumn{3}{|c|}{ Girls } & \multicolumn{3}{|c|}{ All } \\
\hline & $N_{\text {case }}$ & OR & $95 \% \mathrm{Cl}$ & $N_{\text {case }}$ & $\mathrm{OR}$ & $95 \% \mathrm{Cl}$ & $\mathrm{N}_{\text {cass }}$ & OR & $95 \% \mathrm{Cl}$ \\
\hline \multicolumn{10}{|c|}{$<2500 \mathrm{~g}$ versus $\geq 2500 \mathrm{~g}$} \\
\hline $\begin{array}{l}\text { Westcoast cohort } \\
\text { Eastcoast cohort }\end{array}$ & $\begin{array}{l}43 \\
28\end{array}$ & $\begin{array}{l}1.0 \\
1.45\end{array}$ & $0.82-2.53$ & $\begin{array}{l}63 \\
37\end{array}$ & $\begin{array}{l}1.0 \\
1.08\end{array}$ & $\frac{-67-1.71}{0 .}$ & $\begin{array}{r}106 \\
65\end{array}$ & $\begin{array}{l}1.0 \\
1.25\end{array}$ & $\frac{-}{0.87-1.77}$ \\
\hline \multicolumn{10}{|c|}{$<3000 \mathrm{~g}$ versus $\geq 3000 \mathrm{~g}$} \\
\hline $\begin{array}{l}\text { Westcoast cohort } \\
\text { Eastcoast cohort }\end{array}$ & $\begin{array}{l}136 \\
108\end{array}$ & $\begin{array}{l}1.0 \\
1.95\end{array}$ & $1.44-2.63$ & $\begin{array}{l}219 \\
130\end{array}$ & $\begin{array}{l}1.0 \\
1.13\end{array}$ & $0.86-1.47$ & $\begin{array}{l}355 \\
238\end{array}$ & $\begin{array}{l}1.0 \\
1.44\end{array}$ & $1.18-1.76$ \\
\hline
\end{tabular}

$2500 \mathrm{~g}$ as the cut point, and OR $1.60,95 \%$ CI 1.14 2.24, using $3000 \mathrm{~g}$ as the cut point). In addition, separate analyses with respect to smoking status, adjusted for gender, maternal age, parity, and marital status, gave an odds ratio equal to 1.22 (95\% CI $0.76-1.93$ ) for the nonsmokers, as compared with 1.62 (95\% CI 0.76 3.49) for those smoking $1-9$ cigarettes per day and $3.00(95 \%$ CI 1.38 - 6.81) for those smoking at least 10 cigarettes per day, with $3000 \mathrm{~g}$ as the cut point. Hence smoking status seems to be an effect modifier (like gender) although it did not interact significantly with coast affiliation in the previous analyses.

Birthweight is usually registered exactly and is well recorded, whereas it is more difficult to get a good estimate of gestational length (18). Therefore, we have considered birthweight rather than small for gestational age. Nevertheless, we summarize the corresponding effects of cohort affiliation on being small for gestational age using the definitions given by Pradat (19) (see the appendix): the overall odds ratio was $1.64(95 \%$ CI 1.13 2.38), whereas the odds ratio was 1.77 (95\% CI 1.02$3.05)$ for the boys and $1.52(95 \% \mathrm{Cl} 0.89-2.58)$ for the girls, adjusted for maternal age, parity, marital status, and smoking habits in early pregnancy. Hence, the effects on being small for gestational age were similar to those on birthweight.

There was no difference in the length of the infants from the two cohorts (table 5), but the head circumferences of the infants from the eastcoast cohort were slight- ly smaller $(\mathrm{P}<0.001)$, even when multiple births and infants with major malformations were excluded.

\section{Fish consumption}

Both the east- and westcoast women who were interviewed ate locally caught fish more than twice as often as their referents (table 2). The pattern was the same for the estimated average amount consumed (table 7). There were no differences between the east- and westcoast cohorts in the number of fatty fish meals per month or the average amount consumed (tables 2 and 7). However, the westcoast cohort ate lean fish almost twice as often, and twice the amount, as the eastcoast cohort (tables 2 and 7). Of the eastcoast cohort 32\% had decreased and $8 \%$ had increased their consumption of locally caught fish during the last 10 to 20 years, compared with 39 and $18 \%$, respectively, for their referents. The corresponding proportions for the westcoast cohort and its referents were 29 and 32 and 32 and $23 \%$, respectively.

\section{Other dietary habits and coffee, tobacco and alcohol consumption}

With the exception of the higher fish consumption already mentioned and a slightly higher intake of potatoes among the eastcoast and westcoast women compared with their referents, there were no evident differences in dietary habits or coffee, tobacco and alcohol consumption (tables 2 and 3). Moreover, the eastcoast cohort did 
Table 7. Consumption of four species of locally caught fish for 38 wives of fishermen from the east coast and 31 from the west coast and 69 referents, matched by age and county.

\begin{tabular}{|c|c|c|c|c|c|c|c|c|c|c|c|}
\hline & \multicolumn{5}{|c|}{ Fishermen's wives } & \multicolumn{6}{|c|}{ Referents } \\
\hline & \multicolumn{2}{|c|}{$\begin{array}{l}\text { East coast } \\
(N=38)\end{array}$} & \multicolumn{2}{|c|}{$\begin{array}{l}\text { West coast } \\
(N=31)\end{array}$} & \multirow[t]{2}{*}{ P-value ${ }^{a, b}$} & \multicolumn{2}{|c|}{$\begin{array}{l}\text { East coast } \\
(N=38)\end{array}$} & \multirow[t]{2}{*}{ P-value b,c } & \multicolumn{2}{|c|}{$\begin{array}{l}\text { West coast } \\
(\mathrm{N}=31)\end{array}$} & \multirow[t]{2}{*}{ P-value ${ }^{\mathrm{b}, \mathrm{c}}$} \\
\hline & Mean & $\mathrm{SD}$ & Mean & $S D$ & & Mean & SD & & Mean & SD & \\
\hline \multicolumn{12}{|c|}{$\begin{array}{l}\text { Locally caught fatty fish species } \\
\left(\mathrm{kg} \cdot \text { month }^{-1}\right)\end{array}$} \\
\hline $\begin{array}{l}\text { Salmon } \\
\text { Herring }\end{array}$ & $\begin{array}{l}0.21 \\
0.40\end{array}$ & $\begin{array}{l}0.43 \\
0.72\end{array}$ & $\begin{array}{l}0.37 \\
0.12\end{array}$ & $\begin{array}{l}0.43 \\
0.31\end{array}$ & $\begin{array}{l}0.01 \\
0.01\end{array}$ & $\begin{array}{l}0.10 \\
0.07\end{array}$ & $\begin{array}{l}0.18 \\
0.13\end{array}$ & $\begin{array}{l}0.4 \\
0.002\end{array}$ & $\begin{array}{l}0.10 \\
0.06\end{array}$ & $\begin{array}{l}0.17 \\
0.12\end{array}$ & $\begin{array}{l} \\
>0.001 \\
>\end{array}$ \\
\hline Total & 0.61 & 0.92 & 0.49 & 0.51 & $>0.5$ & 0.17 & 0.24 & 0.02 & 0.16 & 0.21 & 0.005 \\
\hline \multicolumn{12}{|c|}{$\begin{array}{l}\text { Locally caught lean fish species } \\
\left(\mathrm{kg} \cdot \mathrm{month}^{-1}\right)\end{array}$} \\
\hline $\begin{array}{l}\text { Flat fish } \\
\text { Cod-filet }\end{array}$ & $\begin{array}{l}0.51 \\
0.46\end{array}$ & $\begin{array}{l}1.12 \\
0.57\end{array}$ & $\begin{array}{l}1.66 \\
0.64\end{array}$ & $\begin{array}{l}1.70 \\
0.55\end{array}$ & $\begin{array}{c}<0.001 \\
0.06\end{array}$ & $\begin{array}{l}0.24 \\
0.13\end{array}$ & $\begin{array}{l}0.54 \\
0.26\end{array}$ & $\begin{array}{l}0.07 \\
0.001\end{array}$ & $\begin{array}{l}0.61 \\
0.31\end{array}$ & $\begin{array}{l}0.97 \\
0.47\end{array}$ & $\begin{array}{l}0.001 \\
0.003\end{array}$ \\
\hline Total & 0.97 & 1.38 & 2.30 & 1.90 & $<0.001$ & 0.38 & 0.72 & 0.003 & 0.93 & 1.34 & $<0.001$ \\
\hline
\end{tabular}

a Comparison between the cohort women from the east and west coast.

b P-values for the Mann-Whitney test.

c Comparison between the cohort women and their local referents.

not differ from the westcoast cohort in any other dietary aspect than fish consumption.

\section{Discussion}

The main finding of the present study was the increased risk for low birthweight in the eastcoast cohort. Similar results were obtained using small for gestational age as the outcome variable.

These results are based on data from the Medical Birth Register, in which almost every birth in Sweden since 1973 has been registered. The quality of birthweight data has been good in this register (20).

It is important to consider different possible explanations for the observed differences in birthweight between the cohorts. Maternal age, parity, and gender are well known risk factors for low birthweight (18), but the discrepancy between the cohorts remained even after adjustment for these factors. The socioeconomic status of women has also a predictive value for birthweight (18), but comparing two cohorts of women married to fishermen reduces the impact of this problem. This assumption is supported by the fact that $76 \%$ of the women in both the eastcoast and the westcoast cohorts were employed during the pregnancy, and 38 and $40 \%$, respectively, were employed full-time. Moreover, according to census data from $1985,62 \%$ of the women married to a fisherman on the east coast and with a gainful occupation had a blue-collar job, as compared with 53\% for the corresponding group from the west coast (Bengt Källén, personal communication). The socioeconomic homogeneity between the cohorts is important for valid comparisons. However, caution should be taken when comparisons with referents from respective regions are interpreted. This need can be illustrated by the fact that, on the whole, infants born to noncohabiting women (about 17\%) have a lower birthweight than infants born to cohabiting women (21) and that the cohorts included only women who were, or had been married, while the reference populations also included women who had never been married. This may be an explanation for the significantly decreased risk for low birthweight among the westcoast cohort.

The height of mothers is a weak predictor of birthweight (Källén, personal communication), and therefore the slight cohort difference in the mothers' heights is an implausible explanation for the increased risk of the eastcoast cohort giving birth to infants with low birthweights. Moreover, the quality of the data on the height of mothers from the Medical Birth Register was available only from 1982 and onwards, and it was acceptable but not good (20).

Smoking during pregnancy is an important risk factor for low birthweight (18), and therefore it was adjusted for in our study. The effect of cohort affiliation for low birthweight was mainly seen among the women smoking during early pregnancy. Unfortunately this analysis could only be based on data from about $40 \%$ of the pregnancies (from 1982 and onwards). Whether there was a similar association during the preceding period remains unknown. Smoking status during late pregnancy, which was unfortunately not registered, is a more important risk factor for low birthweight than smoking status during early pregnancy (22). If the continuation of smoking during pregnancy differed between our cohorts, it could have partly explained our findings. The highest smoking category used in the Medical Birth Register is open ( $>10$ cigarettes a day). Thus smoking women from the eastcoast cohort could hypothetically smoke more cigarettes a day than the smoking women in the westcoast cohort and still be classified into the same cate- 
gory. Such an occurrence could result in some residual confounding of smoking not adjusted for in the analyses. Another explanation of the present results might be a synergistic effect of smoking and exposure to certain xenobiotics. Thus the reason for the observed cohort difference in risk for giving birth to an infant with a low birthweight may be an average higher body burden of $\mathrm{PCB}$ and other persistent organochlorine compounds in the women from the eastcoast cohort. The women interviewed in the westcoast cohort claimed an almost as high consumption of locally caught fatty fish as those from the eastcoast cohort, but the PCB content in fish from Skagerrak and Kattegatt, on the Swedish west coast, is much lower than in fish from the Baltic Sea (23). Eastcoast fishermen have been shown to have about two times higher plasma levels of various PCB congeners than fishermen from the west coast; for all congeners the value is about 2300 versus about $1300 \mathrm{ng} \cdot \mathrm{g} \mathrm{lipid}^{-1}$ (14). The PCB levels in human milk from Swedish women from the general population have decreased since the early 1970 s (24). This fact, taken together with the observed decrease in consumption of locally caught fish, makes it probable that the mean body burden of women giving birth during the study period in the east coast cohort (1973-1991) was higher than the current mean body burden. Calendar year of birth was, however, not an independent risk factor for low birthweight.

The Yusho and Yucheng poisoning incidents were caused by the ingestion of rice oil contaminated with PCB and PCDF (5-8). In both episodes toxicity was evident in children and adults who consumed large quantities of contaminated oil. The Yucheng children exposed in utero were small for gestational age at birth and had a decreased weight gain and behavioral and cognitive impairments. It has also been shown in animal experiments that prenatal PCB exposure causes both reduced birthweight and neurodevelopmental disturbances in litters $(1-4)$.

An important question is whether substantially lower exposure levels for PCB may also entail similar risks. Of great concern with respect to this issue are the studies performed on sport fishermen's wives in the Lake Michigan area in the United States. Prenatal PCB exposure through the maternal consumption of contaminated fish has been associated with reduced birthweight (infants small for gestational age) among newborn (9) and with negative effects on neonatal behavioral performance tests (10). Furthermore, follow-up studies on these children at four years of age have shown both reduced weight gain and decreased motor and cognitive functions $(11,12)$. It has previously been shown that, in Sweden, the consumption of fatty fish from the Baltic Sea is the main dietary source for exposure to both $\operatorname{PCB}(14,15)$ and PCDD and PCDF $(14,25)$. A direct comparison of PCB exposure levels between the fish-eating mothers from the Lake Michigan area and consumers of fatty fish from the Baltic Sea is hampered by differences in the analytical techniques that were used. According to a recent risk evaluation, the exposure levels can, however, be considered comparable (16).

The present data may indicate a possible association between a high body burden of PCB in mothers through the consumption of contaminated fish from the Baltic Sea and an increased risk for low birthweight of their infants. Such an association may have serious implications if PCB-induced low birthweight occurs in parallel with a slight impairment in the neurodevelopment of infants. In order to investigate further the hypothesized association between PCB exposure through fish consumption and decreased birthweight, information on individual dietary and smoking habits is needed. Therefore a case-referent study is now in progress within the cohort of eastcoast women

\section{Acknowledgments}

We are grateful to Mr Jan Gunnarskog and Mr Anders Ericson at the National Board of Health, Stockholm, for the linkage to the Medical Birth Register. We are also indebted to Ms Elisabeth Jurén, Ms Helene Kristoffersson, Ms Petra Törnblad, and Mr Esben Almqvist for performing the dietary interviews.

This work was financed by grants from the Swedish National Environmental Protection Board, the Swedish Work Environment Fund, and the Medical Faculty of the University of Lund.

\section{References}

1. Peterson RE, Theobald HM, Kimmel GL. Developmental and reproductive toxicity of dioxins and related compounds: crossspecies comparisons. CRC Crit Rev Toxicol 1993;23:283335.

2. Tilson HA, Jacobson JL, Rogan WJ. Polychlorinated biphenyls and developing nervous system: cross-species comparisons. Neurotoxicol Teratol 1990;12:239-48.

3. Seegal RF, Shain W. Neurotoxicity of polychlorinated biphenyls: the role of ortho-substituted congeners in altering neurochemical function. In: Isaacson RL, Jensen KF, editors. The vulnerable brain and environmental risks; vol 2 (Toxins in food). New York (NY): Plenum Press, 1992.

4. Morse DC, Groen D, Veerman M, van Amerongen CJ, Köeter HBWM, Smits-van Proije AE, et al. Interference of polychlorinated biphenyls in hepatic and brain thyroid hormone metabolism in fetal and neonatal rats. Toxicol Appl Pharmacol 1993;122:27-33.

5. Rogan WJ, Gladen BC, Hung K-L, Koong S-L, Shih L-Y, Taylor JS, et al. Congenital poisoning by polychlorinated biphenyls and their contaminants in Taiwan. Science 1988;241: $334-6$. 
6. Rogan WJ. PCBs and cola-colored babies: Japan, 1968, and Taiwan, 1979. Teratology 1982;26:259-61.

7. Lai TJ, Chen YC, Chou WJ, Guo YL, Ko HC, Hsu CC Cognitive development in Yucheng children. Organohalogen Compd 1993;14:247-50.

8. Hsu CC, Hu HF, Lai TJ, Ko HC, Chen YC. Behavior development of Yucheng children as compared to their matched controls. Organohalogen Compd 1993; 14:239-42.

9. Fein GG, Jacobson JL, Jacobson SW, Schwartz PM, Dowler JK. Prenatal exposure to polychlorinated biphenyls: effects on birth size and gestational age. J Pediatr 1984;105:315-20.

10. Jacobson JL, Fein GG, Jacobson SW, Schwartz PM, Dowler JK. The transfer of polychlorinated biphenyls (PCBs) and polybrominated biphenyls (PBBs) across the human placenta and into maternal milk. Am J Public Health 1984;74:378-9.

11. Jacobson JL, Jacobson SW, Humphrey HEB. Effects of in utero exposure to polychlorinated biphenyls and related contaminants on cognitive functioning in young children. $\mathrm{J}$ Pediatr 1990;116:38-45.

12. Jacobson JL, Jacobson SW, Humphrey HEB. Effects of exposure to PCBs and related compounds on growth and activity in children. Neurotoxicol Teratol 1990;12:319-26.

13. Svensson B-G, Mikoczy Z, Strömberg U, Hagmar L. Mortality and cancer incidence among Swedish fishermen with a high dietary intake of persistent organochlorine compounds. Scand J Work Environ Health 1995;21:106-115.

14. Svensson B-G, Nilsson A, Jonsson E, Schuitz A, Åkesson B, Hagmar L. Fish consumption and exposure to persistent organochlorine compounds, mercury, selenium and methylamines in Swedish fishermen. Scand $\mathbf{J}$ Work Environ Health $1995 ; 2: 96-105$

15. Asplund L, Svensson BG, Nilsson A, Eriksson U, Jansson B, Jensen $S$, et al. PCB, p,p'-DDT and p,p'-DDE in human plasma related to fish consumption. Arch Environ Health. In press.

\section{Appendix}

\section{Estimation of growth retardation}

To estimate growth retardation, the following third-degree polynomials fitted with the least square method and based on data from the Swedish Medical Birth Register were used:

$$
\text { boys } \begin{aligned}
\bar{y}= & 11449.78-1254.351 \cdot x+43.96213 \cdot x^{2} \\
& -0.4359399 \cdot x^{3}
\end{aligned}
$$

and

$$
\begin{aligned}
\text { girls } \bar{y}= & 27399.31-2652.778 \cdot x+84.26283 \cdot x^{2} \\
& -0.8216029 \cdot x^{3}
\end{aligned}
$$

where $\bar{y}$ is the expected weight and $\mathrm{x}$ is the length of gestation (in weeks)

These equations were based on the following assumptions:

The majority of the infants born in a given week were "normal." The mean weight of "normal" infants during a
16. Ahlborg UG, Hanberg A, Kenne K. Risk assessment of polychlorinated biphenyls (PCBs). Copenhagen: Nordic Council of Ministers, 1992. Nord 1992:26.

17. Hagmar L, Lindén K, Nilsson A, Norrving B, Åkesson B, Schütz A, et al. Cancer incidence and mortality among Swedish Baltic Sea fishermen. Scand J Work Environ Health $1992 ; 18: 217-24$.

18. Källén B. Epidemiology of human reproduction. Boca Raton (FL): CRC Press Inc, 1988.

19. Pradat P. Epidemiological characteristics of major congenital heart defects [dissertation]. Lund: Department of Embryology, Lund University, 1994.

20. Cnattingius $\mathrm{S}$, Ericson A, Gunnarskog J, Källén B. A quality study of a medical birth registry. Scand J Soc Med 1990;18:143-8.

21. Ericson A, Eriksson M, Källén B, Zetterström R. Socio-economic variables and pregnancy outcome. Acta Paediatr Scand Suppl 1989;360:48-55.

22. Ahlsten $\mathrm{G}$, Cnattingius $\mathrm{S}$, Lindmark $\mathrm{G}$. Cessation of smoking during pregnancy improves foetal growth and reduces infant morbidity in the neonatal period: a population-based prospective study. Acta Paediatr 1993;82:177-81.

23. Asplund L, Jansson B, de Wit C, Bergek S, Hjelt M, Rappe C et al. Polychlorinated dibenzo-p-dioxins (PCDD) and dibenzofurans (PCDF) compared to other organohalogen pollutants in biological samples from Swedish ecosystems. In: Proceedings of the 10th International Symposium on Chlorinated Dioxins and Related Compounds, Dioxin '90; vol 1. Bayreuth, (Germany): Ecoinforma Press, 1990;1:405-8.

24. Norén K, Lundén $\AA$. Trend studies of polychlorinated biphe nyls, dibenzo-p-dioxins and dibenzofurans in human milk. Chemosphere 1991;23:1895-901.

25. Svensson BG, Nilsson A, Hansson M, Rappe C, Åkesson B Skerfving $\mathrm{S}$. Exposure to dioxins and dibenzofurans through the consumption of fish. N Engl J Med 1991;324:8- 12 .

specific week can therefore be estimated from the mode of the weight distribution. In addition the dispersion was proportional to the mean weight. As most infants born in week 40 are normal, the dispersion was estimated at this week, and it was shown that it represented approximately $12 \%$ of the mean weight for both the boys and the girls.

If $\mathrm{SD}$ represents the standard deviation, it is

$\mathrm{SD}=0.12 \cdot \overline{\mathrm{y}}$.

For each infant, the deviation in terms of standard deviation was calculated as

deviation $=(y-\bar{y}) /(0.12 \cdot \bar{y})$.

When the deviation was less than -2 , the infant was regarded as growth retarded (small for gestational age). 